\title{
Productivity of Early Maturing Varieties of Potatoes, With the Application of Designated Doses of Fertilizers, Within the Conditions of the Forest-Steppe of the Middle Volga Region
}

\author{
Antonina A. Mostyakova ${ }^{1}$, Konstantin V. Vladimirov², Artur Y. Tyaminov ${ }^{3}$, Vladimir P. \\ Vladimirov $^{4}$, Aleksandr L. Mikhailov ${ }^{5}$. \\ 1, 5 Kazan Federal University, ${ }^{2}$ FGBI "Agrochemical Service Center "Tatar", ${ }^{3,4}$ Kazan State Agrarian \\ University \\ Email.runga540@mail.ru, Contact.89046788345
}

Received: 21st October 2017 Accepted: 16th November 2017, Published: 31st December 2017

\begin{abstract}
The studies were carried out with the purpose to determine the effectiveness of applying the designated doses of fertilizers for the formation of planned yields of potato tubers of the early-ripening varieties Molly and Colette, within the conditions of the forest steppe of the Middle Volga region. The influence of mineral nutrient status, designed for obtaining the yields of potatoes 25, 35 and 45 tons/ha, in comparison with the unfertilized controlvariant, has been studied.

The analysis of the dynamics of the potato plants leaf area, the parameters of leaf photosynthetic potential, the utilization coefficient of photosynthetically active radiation (PAR)showed, that these indicators of photosynthetic activity were directly dependent on the level of mineral nutrition.

The application of fertilizers and raising their doses increased the value of photosynthetic potential (PP). In the control variant, without applying fertilizers, the sum of photosynthetic potential was 1.762 million for the variety Molly, 1.894 million $\mathrm{m}^{2} /$ ha $\times$ days for the variety Colette. The application of fertilizers, designed for a potato yield of 25 tons per hectare, has increased this index by 1.49 and 1.51 times, and the fertilization, designed for the yield 45 t/ha has increased this index by 2.25 and 2.01 times. For every 1 thousand units, the PP was formed in the variety Molly from $10.15 \mathrm{~kg}$ in the control variant to $11.25 \mathrm{~kg}$ of potato tubers with underlying of $45 \mathrm{t} / \mathrm{ha}$, and in the variety Colette, respectively, from 10.32 to $11.45 \mathrm{~kg}$.

With regard to natural fertility, theyield of varietyMolly was $16.76 \mathrm{t} / \mathrm{ha}$ and $18.32 \mathrm{t} / \mathrm{ha}$ of thevariety Colette. Fertilizers, designed for 25-45 t/ha of potato tubers, ensured the yield of variety Molly 28.23-43.57 t/ha, the variety Colette $-29.72-29 \mathrm{t} / \mathrm{ha}$.
\end{abstract}

Keywords: Variety, Fertilizer, Balance Method, Sprouts, Leaf Surface, Photosynthetic Potential, Utilization Coefficient of PAR, Dry Weight of Potato Tubers, Yield.

\section{Introduction}

Potatoes require a lot of nutrientsfor obtaining a high yields with good quality of tubers. Nutrients should be available to plants in the required amount and form. Such requirements are met by fertilizers, designed taking into account the content of nutrients in the soil and the coefficients of use of applied fertilizers. [Gifford, 1987; DiterShpaar, 2016; Korshunov, 1982; Sturm, Buchner, Zerulla, 1994]. Organic fertilizers, which along with increased yields improve the taste of the tubers, are of particular value in the cultivation of potatoes [Pisarev, 1990]. They enrich the soil with macro - and microelements. When decomposed, carbon dioxide is released, which is used by the leaves of potato plant as an additional source of carbon nutrition, since it is in short supply for the formation of high yields of 30-40 t/ha or more. Organic fertilizers enrich the soil with a large number of beneficial microorganisms, which transform unavailable compounds into digestible form. Organic fertilizers contribute to the accumulation of humus in the soil, improve its physical properties. Comparatively slow decomposition of organic fertilizers does not allow the full utilization of nutrients at the primary period of plant growth. It should be applied suchmineral fertilizers, in which nutrients are in the form of readily accessible to plants, in order to provide nutrients in the early period of potato plants life.

In the experiments of M.K. Koksharova and Sh.N. Karmanova [2002], within the conditions of the Middle Urals, the application of a fertilizer dose for potatoes of the variety Granat $\mathrm{N}_{90} \mathrm{P}_{180} \mathrm{~K}_{180}$, yielded a crop of tubers - $35.1 \mathrm{t} / \mathrm{ha}$, in comparison with 15.0 $\mathrm{t} / \mathrm{ha}$ in the control variant, where no fertilizers were applied.

In the Moscow region the variety Nevsky yielded $29.0 \mathrm{t} / \mathrm{ha}$, the variety Golubiznayielded25.3 t/ha, after the application of $\operatorname{doseN}_{100} \mathrm{P}_{150} \mathrm{~K}_{150}$. [Korshunov, Semenov, 2003].

In the studies of Yu.P. Zhukov and T.I. Volodina [2001] on the dark chestnut soils of Northern Kazakhstan, the potato yield was $23.0-24.0$ t/ha, after application of $\mathrm{N}_{90} \mathrm{P}_{90} \mathrm{~K}_{90}$.

I.I. Sinyagin [1970], carrying out experiments on leached chernozem of Eletsk experimental station of the Research Institute of Potato Farming, defined that the yield of $33 \mathrm{t} / \mathrm{ha}$ (an increase as a result of fertilizers application $15.5 \mathrm{t} / \mathrm{ha}$ ) was formed when applying a dose of fertilizers $\mathrm{N}_{180} \mathrm{P}_{210} \mathrm{~K}_{210}$. 
In England, at the experimental station Stockbridge House, fertilizers are applied at the dose and the ratio $\mathrm{N}_{254} \mathrm{P}_{505} \mathrm{~K}_{381} \mathrm{~kg} / \mathrm{ha}$ for the planned yield of potatoes tubers (82.5 t/ha) [Evans S., 1975].

As a result of studies, carried out in Finland and England (the Rotamsted Experimental Station), different response of varieties for different fertilizer doses was noted (Edinger, 1976; Varis, 1973; Widdowson, Penny, 1975].

Many researchers note that high doses of fertilizers worsen the state of microbiological community, which has a significant impact on the nutritive regime of plants in the soil, the yield and the improvement of soil fertility [Mishustin, 1972; Vyblov, 1979; Mikhnovskaya, 1982; Kautskaya, 1982].

V.G. Mineev, E.Kh. Rempe [1991] state, that the potential productivity of an agricultural crop should not be achieved with the help of high doses of fertilizers, but with the optimization of vital processes in the soil, that promotes the reproduction of its fertility without a negative change of microbiocenosis.

\section{Materials and Methods}

The studies were conducted in 2014-2016 on gray forest soil of medium loam granulometric composition of the experimental field of the department of plant growing and horticulture of the Kazan State Agricultural University. The humus content in the experiment is $3.33-3.46 \%, \mathrm{pH}$ sal. 5.48-5.74, mobile phosphorus - 123-132 and exchangeable potassium - 146-163 mg/kg of soil. The predecessor is winter wheat. The plot area is 72 $\mathrm{m}^{2}$; the accounting area is $60 \mathrm{~m}^{2}$. Seed tubers with the medium fraction (60-65 g) were used for planting. Planting was carried out at a depth of $8-10 \mathrm{~cm}$ with a density of 53.2 thousand pieces/ha. Fertilizers were calculated by the balance method for obtaining planned yields of potato tubers.

Variants of the experiment: 1. Control variant (without fertilizers). 2. For yield $25 \mathrm{t} / \mathrm{ha}\left(\mathrm{N}_{47-52} \mathrm{P}_{75}\right.$ ${ }_{90} \mathrm{~K}_{142-148}$ ). 3. Calculation for yield $35 \mathrm{t} / \mathrm{ha}$ (manure 20 $\mathrm{t} / \mathrm{ha}+\mathrm{N}_{93-125} \mathrm{P}_{115-125} \mathrm{~K}_{170-180)}$. 4. Calculation for yield $45 \mathrm{t} / \mathrm{ha}$ (manure $40 \mathrm{t} / \mathrm{ha}+\mathrm{N}_{138-165} \mathrm{P}_{150-165} \mathrm{~K}_{197-211}$ ).

Half-fermented manure was applied in fall tillage. In spring, the ridges with a row spacing of $75 \mathrm{~cm}$ were cut. During the planting, the tubers were pretreated with a fungicide Prestige KS $(1.0 \mathrm{l} / \mathrm{t}$, with a working fluid flow - 10 1/t). Herbicide Zenkor Techno VDG, with a rate of application $1.2 \mathrm{~kg} / \mathrm{ha}$ was used for weeds control. Fungicide Ridomil Gold MC (2.5 $\mathrm{kg} / \mathrm{ha})$, Shirlan SK $(0.4 \mathrm{l} / \mathrm{ha})$ and copper-containing preparations were used for dealing with potato late blight.

The dry matter content was determined by drying to constant weight, alkaline hydrolyzed nitrogen in the soil was defined according to A.Kh. Kornfield, mobile phosphorus - according to Kirsanov, exchangeable potassium - by flamephotometric method, humus - according to Tyurin, $\mathrm{pH}$ sal. Was determined by the method of Central Research Institute of Agrochemical Service(OST 4649-76). Leaf surface and photosynthetic potential were determined according to the formulas, proposed by A.A. Nichiporovich et al. (1961). Starch was defined according to Evers, nitrates - by potentiometric method, and vitamin $\mathrm{C}$ was determined according to I.K. Murri. Statistical processing of the research results was carried out using the method of variance analysis in Microsoft Excel 1997.

\section{Result and Discussion}

More active photosynthetic activity of plants of both varieties was noted after applying of increased mineral nutrition. At the beginning of vegetation, the leaf area, depending on the variant of the experiment, was from 10.02 to 12.82 thousand $\mathrm{m}^{2} / \mathrm{ha}$. The leaf area in all variants of the experiment reached its maximum at the stage of flowering. In the control variant of the variety Molly, its value was 25.75 thousand, and in the variety Colette - 26.56 thousand $\mathrm{m}^{2} /$ ha. After the application of fertilizers, designed for a yield $45 \mathrm{t} / \mathrm{ha}$, the leaf area, depending on the variety, increased by 1.98-2.19 times, compared to the control variant.

The sum of photosynthetic potential (PP) for the growing period of plants, without application of fertilizers, in the variety Molly was $1,762,000$ $\mathrm{m}^{2} / \mathrm{day} / \mathrm{ha}$, and in the variety Colette it was higher by $132,000 \mathrm{~m}^{2} / \mathrm{day} / \mathrm{ha}$. Due to the higher nutrition status, the value of photosynthetic potential has increased by 869-2208 thous. in the variety Molly, and in the variety Colette it has increased by $964-1925$ thous. $\mathrm{m}^{2}$ $\times$ day/ha.

The application of fertilizers significantly increased the yield of dry biomass from a unit area in both studied varieties. So, it has exceeded the control variant by 6.641 and $5.89 \mathrm{t} / \mathrm{ha}$, after the application of fertilizers, designed for yield $45 \mathrm{t} / \mathrm{ha}$ (Table 1 ).

The productivity of 1 thousand units of photosynthetic potential (PP) in both varieties was higher after the application of fertilizers, designed for yield $45 \mathrm{t} / \mathrm{ha}$. Having this nutrient status, the yield of variety Molly was $11.25 \mathrm{~kg}$ of tubers per thousandsof $\mathrm{PP}$, and the variety Colette $-11.45 \mathrm{~kg}$.

In the course of raising the status of mineral nutrition, the utilization coefficient of PAR has been increased. The variety Molly had the highest value of this parameter $(2.94 \%)$, after the fertilization, designed for a yield $45 \mathrm{t} / \mathrm{ha}$, that is by 1.91 times higher than in the control variant. 
Table 1 -The Indicators of Productivity of Potato Plantings, at Different Levels of Mineral Nutrition, 2014-2016

\begin{tabular}{|c|c|c|c|c|c|}
\hline Variety & $\begin{array}{c}\text { Planned yield, } \\
\text { t/ha }\end{array}$ & $\begin{array}{l}\text { Yield of dry } \\
\text { biomass, } \mathrm{t} / \mathrm{ha}\end{array}$ & $\begin{array}{l}\text { Average daily } \\
\text { increase in dry } \\
\text { biomass, } \mathrm{kg} / \mathrm{ha}\end{array}$ & $\begin{array}{l}\text { Productivity of } \\
\text { leaves, kg of } \\
\text { tubers per } \\
\text { thousand units of } \\
\text { PP }\end{array}$ & $\begin{array}{c}\text { Utilization } \\
\text { coefficient of PAR, } \\
\%\end{array}$ \\
\hline \multirow[t]{4}{*}{ Molly } & $\begin{array}{c}\text { Without } \\
\text { fertilization }\end{array}$ & 7,331 & 81,18 & 10,15 & 1,54 \\
\hline & 25 & 9,873 & 109,34 & 11,17 & 2,08 \\
\hline & 35 & 12,012 & 133,02 & 10,61 & 2,53 \\
\hline & 45 & 13,972 & 154,73 & 11,25 & 2,94 \\
\hline \multirow[t]{4}{*}{ Colette } & $\begin{array}{c}\text { Without } \\
\text { fertilization }\end{array}$ & 7,982 & 88,39 & 10,32 & 1,68 \\
\hline & 25 & 10,294 & 114,00 & 10,83 & 2,17 \\
\hline & 35 & 11,875 & 131,51 & 10,21 & 2,50 \\
\hline & 45 & 13,872 & 153,62 & 11,45 & 2,92 \\
\hline
\end{tabular}

Valuable information on the specific ecological conditions of the soil environment is provided by the indicators of the biological activity of the soil. One of the indicators of biological activity is the decomposition of linen cloth in the soil.

Our observations showed that the application of calculated doses of mineral and organic fertilizersstimulated the decomposition of linen fabric in the soil. The sack cloth, remaining for 60 days in the soil, has decomposed from 18.42 to $23.24 \%$ in control variant of the variety Colette, depending on the year of the research;in the variety Molly these values were from 19.92 to $22.47 \%$. Maximum decomposition of cellulose was noted against the background of a tuber yield $45 \mathrm{t} / \mathrm{ha}$ in both varieties, studied by us (Table 2).

In variants with fertilization, designed for yieldof potato tubers $35 \mathrm{t} / \mathrm{ha}$, the percentage of cellulose decomposition was $40.85 \%$ for the variety Molly and $38.62 \%$ for the variety Colette, on average for three years. The highest values of cellulose decomposition $(48.75 \%$ and $50.08 \%)$ were defined against the background of fertilization, designed for yield $45 \mathrm{t} / \mathrm{ha}$ of potato tubers.

Table 2 - The Influence of Potato Varieties and Mineral Fertilizers for Potato on the Intensity of Cellulose Decomposition in Soil, 2014-2016

\begin{tabular}{|l|l|l|l|l|l|}
\hline Variety & Planned yield, t/ha & \multicolumn{4}{l}{ The percentage of decomposed cellulose after 60 days } \\
\cline { 2 - 6 } & & 2014 & 2015 & 2016 & Average \\
\hline \multirow{5}{*}{ Molly } & Without fertilization & 20,52 & 22,47 & 19,92 & 20,97 \\
\cline { 2 - 6 } & 25 & 37,16 & 38,62 & 32,81 & 36,20 \\
\cline { 2 - 6 } & 35 & 40,68 & 43,18 & 38,70 & 40,85 \\
\cline { 2 - 6 } & 45 & 50,28 & 51,24 & 44,72 & 48,75 \\
\hline \multirow{5}{*}{ Colette } & Without fertilization & 21,14 & 23,24 & 18,42 & 20,93 \\
\cline { 2 - 6 } & 25 & 32,61 & 33,02 & 28,86 & 31,50 \\
\cline { 2 - 6 } & 35 & 38,56 & 53,21 & 36,08 & 38,62 \\
\cline { 2 - 6 } & 45 & 50,26 & 46,84 & 50,08 \\
\hline
\end{tabular}

In our studies, the positive effect of applying the calculated doses of fertilizers on the productivity of both varieties of potato has been revealed. The analysis of yield data showed, that on average, the studied varieties had no significant differences during three years. The highest yield (43.57 t/ha) was obtained after the application of calculated doses of fertilizers, designed for yield $45 \mathrm{t} / \mathrm{ha}$ in the variety Molly (Table 3). 
Table 3 -Yield of Early-Ripening Varieties of Potato, Depending on the Level of Mineral Nutrition, 2014-2016

\begin{tabular}{|c|c|c|c|c|c|}
\hline \multirow[t]{2}{*}{ Variety } & \multirow[t]{2}{*}{ Planned yield, t/ha } & \multicolumn{3}{|c|}{ Yield, t/ha } & \\
\hline & & 2014 & 2015 & 2016 & Average \\
\hline \multirow[t]{4}{*}{ Molly } & Without fertilization & 16,89 & 18,53 & 14,87 & 16,76 \\
\hline & 25 & 28,24 & 29,65 & 26,79 & 28,23 \\
\hline & 35 & 33,86 & 37,25 & 34,42 & 35,18 \\
\hline & 45 & 42,65 & 44,38 & 43,68 & 43,57 \\
\hline \multirow[t]{4}{*}{ Colette } & Without fertilization & 18,34 & 19,28 & 17,35 & 18,32 \\
\hline & 25 & 29,42 & 31,82 & 27,91 & 29,72 \\
\hline & 35 & 34,56 & 36,44 & 34,08 & 35,03 \\
\hline & 45 & 41,46 & 43,64 & 42,53 & 42,54 \\
\hline \multicolumn{2}{|c|}{$\mathrm{HCP}_{05}$ by the factor $\mathrm{A}$} & 0,71 & 0,75 & 1,03 & \\
\hline \multicolumn{2}{|c|}{$\mathrm{HCP}_{05}$ by the factor $\mathrm{B}$} & 0,33 & 0,53 & 0,58 & \\
\hline \multicolumn{2}{|c|}{$\mathrm{HCP}_{05}$ by the factor $\mathrm{AB}$} & 1,79 & 2,01 & 2,41 & \\
\hline
\end{tabular}

\section{Summary}

1. Maximum leaf area of the agrocenosis in the variety Molly (56.45 thousand $\mathrm{m}^{2} / \mathrm{ha}$ ), the largest $\mathrm{PP}$ $\left(3,970,000 \mathrm{~m}^{2} \times\right.$ day/ha) and the utilization coefficient of PAR $(2.94 \%)$ were achieved after fertilization, designed for yield $45 \mathrm{t} / \mathrm{ha}$ of potato tubers. In this version of fertilization, compared to the control variant, these parameters have been increased, on average over three years, respectively, by $2.19 ; 2.25$; 1.91 times.

The yields of potato tubers $25.0 \mathrm{t} / \mathrm{ha}$ and $35.0 \mathrm{t} / \mathrm{ha}$ were formed in the studied varieties, and only at the level of $45 \mathrm{t} / \mathrm{ha}$ they were amounted to $-94.5 \%$ and $96.8 \%$ of the planned level. The shortages of crops against this background were 1.43 and $2.46 \mathrm{t} / \mathrm{ha}$.

The productivity of the variety Molly was higher in control variant, and after the fertilization, designed for a yield $45 \mathrm{t} / \mathrm{ha}$. The fertilization, designed for the yield $25 \mathrm{t} / \mathrm{ha}$, had the advantage in the variety Colette.

\section{Conclusion}

The analysis of the dynamics of leaf area development in potato plants, the parameters of the leaf photosynthetic potential, and the utilization coefficient of PAR showed that photosynthetic activity was directly dependent on the level of mineral nutrition.

One of the conditions for obtaining high and stable yields is the use of fertilizers doses, designed for the planned yields, taking into account the content of nutrition elements in the soil and the coefficients of their utilization from soil and fertilizers.

When planning high yields of potato tubers, organic fertilizers should be applied together with mineral fertilizers. With regard to natural fertility, the yield of variety Molly was 16.76 t/ha of potato tubers and the yield of variety Colette was 18.32 t/ha. Fertilizers, designed for 25-45 t/ha of potato tubers ensured the yield of the variety Molly 28.23-43.57 t/ha, and the variety Colette $-29.72-29$ t/ha.

\section{Acknowledgments}

The work is performed according to the Russian Government Program of Competitive Growth of Kazan Federal University.

\section{References}

[1] Vyblov, N.F. The effect of fertilizers on the microflora of gray forest soils in Gorny Altai / N.F. Vyblov // Microbial associations and their functioning in soils of Western Siberia. Novosibirsk, 1979. - Pp.178-182.

[2] Gifford R.M. The use of scientific achievements in photosynthesis in order to increase the productivity of cultivated plants / R.M. Gifford, L.D. Jenkins // Photosynthesis: in 2 vol./ Trans. from English. Moscow: Mir, 1987, vol. 72. - Pp. 365-410.

[3] Zhukov Yu.P., Volodina T.I.The influence of mineral fertilizers on the yield and quality of potatoes, in case of irrigation of dark chestnut soil // Agrochemistry. - 2001. - №6.-Pp. 35-39.

[4]Kautskaya L.B. Some microbiological indices of the Chernozemic soil deep weakly-leached with prolonged application of fertilizers/ L.B. Kautskaya// Microorganisms as a component of biogeocenosis. Alma-Ata, 1982. - Pp. 115-116.

[5]Korshunov A.V. Increasing of potato fertilizer efficiency / A.V. Korshunov // Works of the Research Institute of Potato Farming, 1982. - Issue. 39. - Pp.324.

[6]Koksharova M.K. Fertilization of seed plantings on peat bogs | M.K. Koksharova, Sh.N. Karmanova // Potatoes and vegetables. - 2002. №7. - Pp. 29.

[7]Korshunov A.V. Methods of agricultural technology affect the yield and its quality / A.V. Korshunov, A.V. Semenov // Potatoes and Vegetables. - 2003. - № 3. - Pp. 8-9.

[8] Makarov B.N. Soil respiration and the role of this process in the carbon nutrition of plants/ B.N. Makarov // Agrochemistry, 1993. - № 8. - Pp. 94104.

[9]Mineev V.G. Ecological consequences of prolonged use of increased and high doses of mineral 
fertilizers/ V.G. Mineev, E.Kh.Rempe // Agrochemistry, 1991. - №3.- Pp. 35-50.

[10]Mishustin E.N. Microorganisms and productivity of agriculture.E.N. Mishustin. - M., 1972. - 343 p.

[11]Mikhnovskaya T.G. Influence of mineral fertilizers on the formation of microbial communities under different conditions of humidity and soil temperature/ T.G. Mikhnovskaya // Structure and functions of microbial communities of soil with different anthropogenic load. - Kiev, 1982. - Pp. 168171.

[12]Pisarev B.A. Varietal agricultural technology of potatoes. - Moscow: VO "Agropromizdat", 1990. $210 \mathrm{p}$.

[13]Sinyagin I.I. Area of plant nutrition / I.I. Sinyagin. Moscow: Rosselkhozizdat, 1970. - 232 p. [14]Shpaar.D. Potatoes. Cultivation, harvesting, storage. / D. Shpaar, A. Bykin, D. Dreger et al.Under the general editorship of D. Shpaar. - M.: LLC "DLV AGRODELO", 2016. - $458 \mathrm{p}$.

[15] Edinger

E.

LohnenderKartoffelbaudurchrichtigeDungung

Fortsch. Landwirtschaft, 1976, Ig. 54, H. 6, s. 3-4.

[16] Evans S. Maximum Potato yield in the United Kingdom. - Outlook on Agr.,1975, v. 8, №14, pp. 184-187.

[17] Sturm H., Buchner A., Zerulla W. Gezielterdungen.- Main: 3. Auft, Verlags Union Agrar Frankfurt-Main, 1994. - $471 \mathrm{~s}$.

[18]Varis E. NPK - IannoituksenVaikutusPitoperunanravinteiden. ottoon. - J. Scient. Agr.Soc. Finland, 1973, v. 45, №5, p. 542-564.

[19]Widdowson,F., Penny A. Results from experiments, measuring the effects of large amounts of NPK fertilizer on yield tuber size and N, P and K contents of three potato varieties. - J. agric. Sci. Camb., 1975, v. 85, №3, pp. 515-525. 